\section{AIDSVAX flop leaves vaccine field unscathed}

HIV vaccine researchers have known for years that VaxGen's AIDSVAX, and others like it, have little chance of inducing antibodies that can neutralize HIV. Some have instead chosen to investigate vaccines that, rather than prevent infection, induce a cellular immune response to destroy infected cells.

As a few of those alternatives inch toward phase 3 trials, however, many scientists now say that a combination of the two approaches offers the best shot at preventing HIV infection.

"The Holy Grail is a candidate that will give you a robust cell-mediated response, together with the neutralizing antibodies that can recognize and defend against a wide range of primary isolates," says Anthony Fauci, director of the US National Institute of Allergy and Infectious Diseases (NIAID).

Not long ago, there were so few vaccine candidates that keeping track of them was an easy task, says Scott Hammer, chief of the Division of Infectious Diseases at Columbia Presbyterian Medical Center in New York. "Now it's a challenge to compress [the information] into a few minutes," he says.

Many of the new candidates are based on the prime-boost approach-a DNA or vector vaccine to destroy infected cells followed by a subunit-based vaccine to induce antibodies. Hammer cites four potential vaccines that are likely to make up the next wave of clinical trials: Merck's adenovirus vaccine; a DNA vaccine with a modified vaccinia Ankara boost, sponsored by the International AIDS Vaccine Initiative (IAVI); an NIAID trial of the Aventis canarypox vaccine; and an Emory University vaccine featuring a DNA prime and a recombinant poxvirus booster.

None of the trials are expected to begin before late 2003 or 2004; candidates face formidable obstacles such as viral diversity and the recently described potential for superinfection. In the meantime, Hammer says, scientists need a better way to predict which candidates will prevent infections in humans. "It's going to be a while before we have true human correlates of infection," he says. "It's absolutely what we need to push the vaccine forward."

The path to a vaccine is littered with abandoned candidates. Last year, NIAID cancelled one phase 3 study of the ALVAC canarypox vaccine when it failed to induce a powerful enough immune response. More recently, Harvard researchers reported that three of four monkeys treated with a promising DNA vaccine have died due to viral breakthrough.

Researchers now know there are at least six human antibodies that can broadly neutralize HIV. Members of IAVI's Neutralizing Antibody Consortium say they have determined the structures of three of those. But retracing the steps to find the immunogens that can elicit those antibodies has been difficult, at best.
When California-based VaxGen announced in February that its HIV vaccine was ineffective in a majority of trial participants, few researchers in the field were surprised. "All the animal studies pointed that way and even the phase 2 trials...suggested that it wouldn't work out-and it didn't," says Dennis Burton (see page 380), professor of immunology at Scripps Research Institute.

The vaccine, which was directed against the gp120 envelope protein, elicited neither neutralizing antibodies (see page 380) nor a cellular immune response, Burton notes. "The science community is pretty angry by now because I think it was a pretty clear failure," he says.

But with those results, VaxGen also revealed the tantalizing possibility that the vaccine conferred $78 \%$ protection in AfricanAmericans and $67 \%$ protection in a group composed of African-Americans, Asians and other minorities. Skeptical scientists were ready with sharp pencils.

Bette Korber of Los Alamos National Laboratory questions how VaxGen derived the $P$ (significance) value for African-Americans and the grouped minorities. "If you move the African [Americans] out, you're left with Asians and 'others' and [the results are] not significant," she says.

In response to press reports questioning its statistical analysis, the company issued a statement saying, "the results... remain accurate as stated, and the analysis continues." But Jim Key, VaxGen's director of communications, now says the data have not been ad-

Although nearly everyone in the field now points to a cocktail of vaccineswhich would induce both antibodies and the cellular immune response-as the solution, there is little evidence to support that premise.

"Intuitively we say we need a combination," says Wayne Koff, IAVI's vice president for research and development, but proof of that principle has yet to be established. Asked how long an effective AIDS vaccine is likely to take, researchers still offer a now-familiar estimate: "five years."

Tinker Ready, Boston

\title{
Skeptical scientists skewer VaxGen statistics
}

justed for multi-group analysis.

Key says the next step is to find a biological explanation for the mixed results. Asked why the company went public with incomplete data analysis, Key says that VaxGen, a publicly traded company, was in a difficult position. Once the data were initially unblinded, he says, the company had to protect the information from leaking out for fear it would influence stock trading. The initial announcement of trial results was fol-

\begin{tabular}{|c|c|c|c|}
\hline \multirow{2}{*}{ All subjects } & Total & $\begin{array}{l}\text { Infected at } \\
\text { end of trial }\end{array}$ & Percentage who became infected \\
\hline & $\begin{array}{l}1,679 \\
3,330\end{array}$ & $\begin{array}{l}98 \\
191\end{array}$ & $\begin{array}{ll}5.8 \% & \text { Placebo } \\
5.7 \% & \text { Vaccine }\end{array}$ \\
\hline \multirow{2}{*}{$\begin{array}{l}\text { White \& Hispanic } \\
\text { Black, Asian, } \\
\text { other combined }\end{array}$} & $\begin{array}{l}1,508 \\
3,003\end{array}$ & $\begin{array}{l}81 \\
179\end{array}$ & $\begin{array}{l}5.4 \\
6.0 \\
\end{array}$ \\
\hline & $\begin{array}{l}171 \\
327\end{array}$ & $\begin{array}{l}17 \\
12\end{array}$ & $\begin{array}{l}9.9 \\
3.7\end{array}$ \\
\hline Black & $\begin{array}{l}111 \\
203\end{array}$ & $\begin{array}{l}9 \\
4\end{array}$ & $\begin{array}{l}8.1 \\
2.0\end{array}$ \\
\hline
\end{tabular}

lowed by an immediate drop in VaxGen's share price from about $\$ 10$ to around $\$ 4$.

Is it possible that a vaccine could selectively protect African-Americans? Human leukocyte antigen (HLA) genotypes could certainly affect both the transmission and cure of certain diseases, says Keith Crawford, director of clinical research at Howard University's School of Pharmacy. But Crawford and others are reserving further judgment until they see a detailed analysis. "[VaxGen] should tell people what they've done," says Korber. "They should explain it to us."

Myrna E. Watanabe, New York 